\title{
Over-Expression, Secondary Structure Characterization, and Preliminary X-ray Crystallographic Analysis of Xenopus tropicalis Ependymin
}

\author{
Jeong Kuk Park, Yeo Won Sim and SangYoun Park * \\ School of Systems Biomedical Science, Soongsil University, Seoul 06978, Korea; water1028@naver.com (J.K.P.); \\ rato0001@naver.com (Y.W.S.) \\ * Correspondence: psy@ssu.ac.kr; Tel.: +82-2-820-0456
}

Received: 19 June 2018; Accepted: 9 July 2018; Published: 11 July 2018

\begin{abstract}
The gene encoding frog (Xenopus tropicalis) ependymin without the signaling sequence was gene-synthesized, and the protein successfully over-expressed in $\sim \mathrm{mg}$ quantities adequate for crystallization using insect cell expression. Circular dichroism (CD) analysis of the protein purified with $>95 \%$ homogeneity indicated that ependymin contains both $\alpha$-helix and $\beta$-strand among the secondary structure elements. The protein was further crystallized using polyethylene glycol 8000 as the precipitating reagent, and X-ray diffraction data were collected to $2.7 \AA$ resolution under cryo-condition at a synchrotron facility. The crystal belongs to a hexagonal space group $\mathrm{P}_{1} 22$ (or P6 522 ) having unit cell parameters of $a=b=61.05 \AA, c=234.33 \AA$. Matthews coefficient analysis indicated a crystal volume per protein mass $\left(\mathrm{V}_{\mathrm{M}}\right)$ of $2.76 \AA^{3} \mathrm{Da}^{-1}$ and $55.4 \%$ solvent content in the crystal when the calculated molecular mass of the protein only was used. However, the apparent SDS-PAGE molecular mass of $\sim 33 \mathrm{kDa}$ (likely resulting from $\mathrm{N}$-glycosylation) suggested $\mathrm{V}_{\mathrm{M}}$ of $1.90 \AA^{3} \mathrm{Da}^{-1}$ and $35.4 \%$ solvent content instead. In both cases, the asymmetric unit of the crystal likely contains only one subunit of the protein.
\end{abstract}

Keywords: ependymin (EPN); ependymin-related protein (EPDR); mammalian ependymin-related protein (MERP)

\section{Introduction}

Ependymin (EPN) was first discovered in the ependymal zone of goldfish brain upon emergence of a learning behavior [1-3]. Additionally, EPN being one of the abundant glycoproteins in the brain extracellular fluid and cerebrospinal fluid in the teleost fish, has been suggested to have various roles in memory consolidation, neuronal regeneration, brain calcium homeostasis $[4,5]$ as well as in cold adaptation, and even in determining aggressiveness [6,7]. Interestingly, orthologues of fish EPN, also exist in other animals such as sea urchin, frog, and even in mammals, and have been also named as EPDR (ependymin-related) protein or MERP (mammalian ependymin-related protein). Humans, in particular, have one isoform of EPN and its expression has been reported in various human normal tissues [8,9]. More interestingly, the transcription level of human EPN was elevated in colorectal tumor cells, and hence is also called UCC1 (upregulated in colorectal cancer gene 1) [10]. Hereafter, all EPN and EPN-like proteins will be mentioned as EPN for simplicity.

EPNs in general contain endoplasmic reticulum-targeting signal sequences at the N-terminus, which are likely cleaved by signal peptidases and further processed for secretion $[9,11]$. The sequences also hold four cysteine residues that may form either intramolecular disulfide crosslinking for stabilizing protein conformation or intermolecular crosslinking for mediating dimeric interaction (Figure 1). Furthermore, studies on fish EPN suggest $N$-glycosylations at two asparagine residues [1,12], 
and other EPNs also have predicted N-glycosylation sites (Figure 1). An isolated digestive fragment of fish EPN has been shown to activate c-Jun N-terminal kinase, and components of AP-1 (c-Jun and c-Fos) via the PKC and MAPK pathways $[13,14]$. Because oxidative stresses induce the expression of AP-1 by the MAP kinase pathway, upregulation of superoxide dismutase (SOD), catalase, and glutathione peroxide have been implied as the downstream targets of at least fish EPN to prevent damages resulting from reactive oxygen species [15].

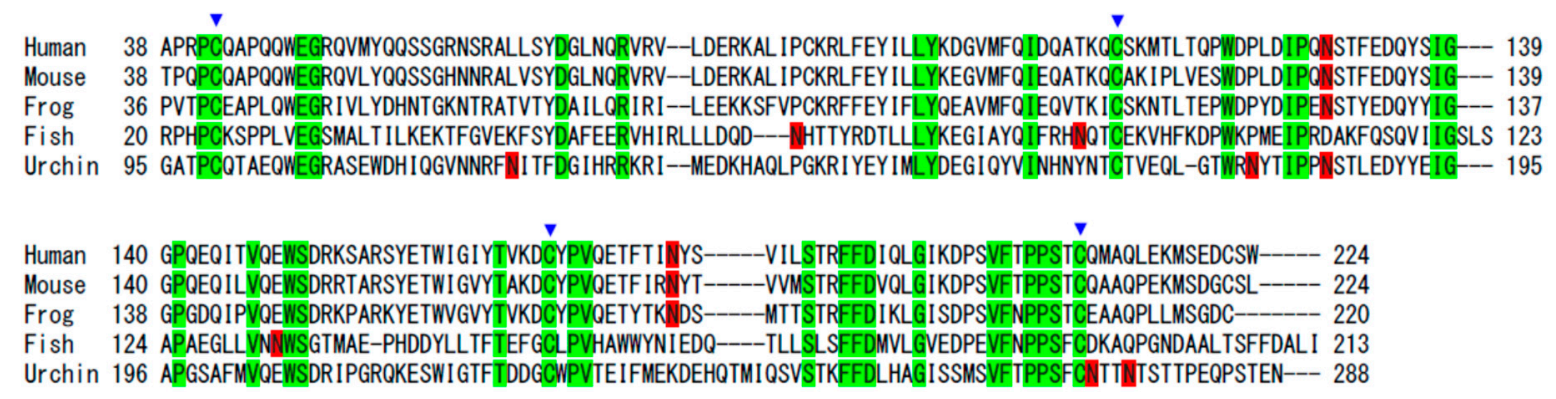

Figure 1. Protein sequence alignment of EPNs (without their $\mathrm{N}$-terminal signal sequence) from various organisms. Homologous residues in all species are in green background. Predicted $N$-glycosylation sites are in red background. The four conserved cysteines are indicated with triangles on top. The mouse sequence is from Mus musculus EPDR2, the fish sequence is from Oncorhynchus mykiss (Rainbow trout), the frog sequence is from Xenopus tropicalis, and the sea urchin sequence is from Strongylocentrotus purpuratus (purple sea urchin). In comparison to the frog EPN sequence expressed in this study, the EPNs of fish (29\%), sea urchin (43\%), human (66\%), and mouse $(65 \%)$ all show sequence conservations (identity percent in parenthesis).

Despite the fact that EPN is similar from sea urchins to humans [16], studies leading to its multi-functional role are limited to EPN of the fish. Furthermore, the detailed mechanism of EPN's action remains yet to be unveiled. Since no known structure of any EPN exists so far, we believe that the future structure of EPN would give directions in predicting the function of EPNs in general. In this attempt, frog (Xenopus tropicalis) EPN without the signal sequence was recombinantly expressed in insect cells and purified. The protein was further crystallized, and the diffraction data obtained in a synchrotron facility.

\section{Materials and Methods}

\subsection{Macromolecule Production}

DNA encoding frog (X. tropicalis) EPN (residues 38 224), which excludes the N-terminal signal sequence was gene-synthesized with an addition of N-terminal His 8 -tag sequence and BamHI/NotI restriction enzyme sites (Bioneer, Daejeon, Korea) for cloning into pAcGP67A vector (BD Biosciences, Franklin Lakes, NJ, USA) (Table 1). The final plasmid generated was sequence verified before using it for transfection into insect cells. The media used for the insect cell culture was Corning ${ }^{\circledR}$ Insectagro $^{\circledR}$ (Thermo Fisher Scientific, Waltham, MA, USA) supplemented with $\times 1$ of Gibco ${ }^{\circledR}$ (Thermo Fisher Scientific, Waltham, MA, USA) Antibiotic-Antimycotic [penicillin 100 units $/ \mathrm{mL}$, streptomycin $100 \mu \mathrm{g} / \mathrm{mL}$, Fungizone ${ }^{\circledR}$ (Amphotericin B) $250 \mathrm{ng} / \mathrm{mL}$. The media was pre-warmed in $27^{\circ} \mathrm{C}$ water bath for $1 \mathrm{~h}$, and the insect cell culture was performed in $27^{\circ} \mathrm{C}$ benchtop or shaking incubators. Transfection of frog EPN containing plasmid and baculovirus DNA into SF9 (Spodoptera frugiperda) cells, and the subsequent virus amplification through multistep infections were performed according to the manufacturer's method. Briefly, a mixture of $0.1 \mu \mathrm{g}$ plasmid and $5 \mu \mathrm{L}$ baculovirus DNA (ProEasy $^{\mathrm{TM}}$, AB vector, San Diego, CA, USA) was pre-mixed and diluted with water to $50 \mu \mathrm{L}$. Into the pre-mix, $50 \mu \mathrm{L}$ of $10 \%$ Profectin $^{\mathrm{TM}}$ (AB vector, San Diego, CA, USA) solution was added dropwise, and incubated at room temperature for $20 \mathrm{~min}$. For transfection into SF9 cells, the resulting $100 \mu \mathrm{L}$ 
mixture was added dropwise to the $50 \%$ confluent cells in a 6-well plate. The cells were harvested after four days of infection to obtain the initial P0 EPN virus stock. All subsequent infections for virus amplification were made by using the virus stock as $\times 20$ stock. Hence, the P1 EPN virus stock was obtained by infecting the P0 stock into 50\% confluent SF9 cells in T75 flask and harvesting after 4 days. Further infection and harvest after 4 days in 50\% confluent SF9 cells in T150 flask generated the P2 EPN virus stock. Subsequently, another infection was made into a suspension culture in $50 \mathrm{~mL}$ SF9 cells $\left(2 \times 10^{6}\right.$ cells $\left./ \mathrm{mL}\right)$ for the P3 EPN virus stock which was harvested in 4 days. The final P4 EPN virus stock was obtained by infecting the P3 EPN virus stock into $200 \mathrm{~mL} \mathrm{SF9} \mathrm{cells}\left(2 \times 10^{6}\right.$ cells $\left./ \mathrm{mL}\right)$. For large-scale protein expression, $50 \mathrm{~mL}$ of P4 EPN virus stock was infected into $1 \mathrm{~L}$ of $2 \times 10^{6}$ cells $/ \mathrm{mL}$ SF9 cells with 140 RPM shaking at $27^{\circ} \mathrm{C}$. The cells were harvested after 2 days to obtain only the supernatant in which the secreted EPN was found.

Table 1. Macromolecule production information for frog EPN.

\begin{tabular}{cc}
\hline Source Organism & Xenopus tropicalis \\
\hline DNA source & Synthesized DNA \\
\hline Cloning sites & BamHI and NotI \\
\hline Cloning vector & pAcGP67A \\
\hline Expression vector & pAcGP67A \\
\hline Expression host & SF9 (S. frugiperda) \\
\hline & ADPHHHHHHHHPVTPCEAPLQWEGRIVLYDH \\
Complete amino acid sequence of the construct produced & NTGKNTRATVTYDAILQRIRILEEKKFVPCK \\
& RFFEYIFLYQEAVMFQIEQVTKICSKNTLTEPWDPY \\
& DIPENSTYEDQYYIGGPGDQIPVQEWSDRKPARK \\
& YETWVGVYTVKDCYPVQETYTKNDSMTTSTRFFDI \\
& KLGISDPSVFNPPSTCEAAQPLLMSGDC \\
\hline
\end{tabular}

\footnotetext{
${ }^{1}$ Non-native $\mathrm{His}_{6}$-tag is underlined.
}

Stock solutions of Tris $\mathrm{pH} 7.5$ and $\mathrm{NaCl}$ were added into the harvested supernatant to a final concentration of $50 \mathrm{mM}$ Tris $\mathrm{pH} 7.5$ and $200 \mathrm{mM} \mathrm{NaCl}$, and further adjusted to $\mathrm{pH} 7$ optimal for Ni-NTA binding. For $\sim 1 \mathrm{~L}$ of supernatant, $20 \mathrm{~mL}$ Ni-NTA resin (Qiagen, Hilden, Germany) was added and rocked at $100 \mathrm{RPM}\left(20^{\circ} \mathrm{C}, 1 \mathrm{~h}\right)$ for bead binding. The mixture was incubated in $4{ }^{\circ} \mathrm{C}$ for $1 \mathrm{~h}$ to allow the separation of resin from the supernatant. The supernatant was carefully removed until $\sim 100 \mathrm{~mL}$ and the re-suspended mixture was packed in a glass column. The resin was further washed with $100 \mathrm{~mL}$ wash buffer ( $20 \mathrm{mM}$ imidazole, $25 \mathrm{mM}$ Tris $\mathrm{pH} 7.5$, and $500 \mathrm{mM} \mathrm{NaCl}$ ), and the frog EPN eluted with $100 \mathrm{~mL}$ elution buffer (200 mM imidazole, $25 \mathrm{mM}$ Tris $\mathrm{pH} 7.5$, and $500 \mathrm{mM}$ $\mathrm{NaCl}$ ) by collecting in fractions of $\sim 10 \mathrm{~mL}$. The frog EPN in the collection fraction was checked on SDS-PAGE, and concentrated to $\sim 10 \mathrm{~mL}$ using Amicon ${ }^{\circledR}$ Ultra-15 centrifugal filter (Merck, Kenilworth, NJ, USA). The concentrated crude protein was further purified using size-exclusion chromatography (SEC) on a ÄKTA FPLC (GE Healthcare, Little Chalfont, UK) connected to Superdex ${ }^{\circledR} 200$ HR26/60 (GE Healthcare, Little Chalfont, UK) pre-equilibrated with gel filtration buffer (50 mM Tris pH 7.5 and $150 \mathrm{mM} \mathrm{NaCl}$ ). FPLC eluate peak of EPN showed one major peak, and was concentrated to yield $\sim 13 \mathrm{mg} / \mathrm{mL}(\sim 200 \mu \mathrm{L})$ of frog EPN protein. Absorptivity coefficient of $\varepsilon=1.8(\mathrm{mg} / \mathrm{mL})^{-1} \mathrm{~cm}^{-1}$ at $\lambda=280 \mathrm{~nm}$ was calculated by using the numbers of tyrosine and tryptophan in the protein [17]. The homogeneity of the final frog EPN was checked using SDS-PAGE under both reducing (with $5 \mathrm{mM}$ DTT) and non-reducing (without DTT) conditions (Figure 2) and the aliquoted protein flash-frozen in liquid nitrogen for storage in $-80^{\circ} \mathrm{C}$. 


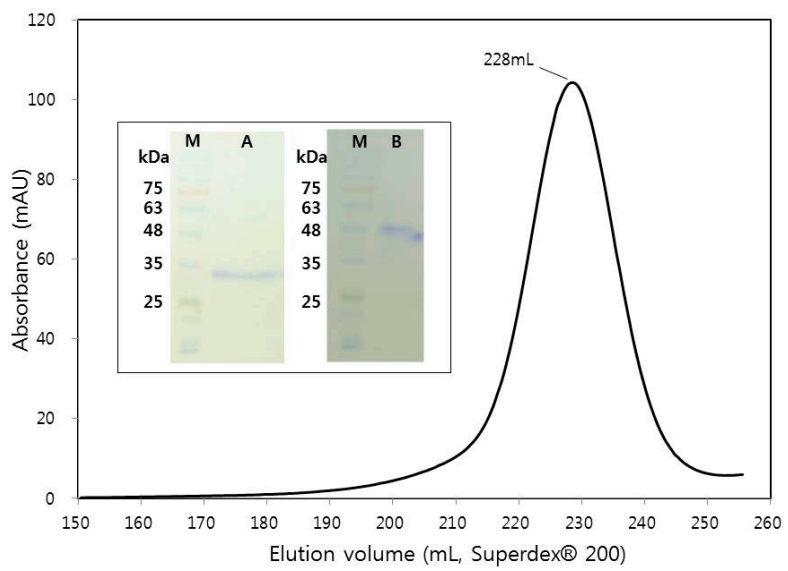

Figure 2. Size-exclusion chromatogram of frog EPN near $228 \mathrm{~mL}$ elution volume with the SDS-PAGE results on the concentrated fractions under the peak (inset). Labels for inset are as follows: Protein standard marker (M); SDS-PAGE under reducing condition (A); SDS-PAGE under non-reducing condition (B).

\subsection{Circular Dichroism (CD)}

Proper folding and further secondary structure element content of the purified frog EPN protein were analyzed using circular dichroism (CD). Ellipticity was scanned over 205 240 nm wavelength on a JASCO spectropolarimeter (Model J-810, Tokyo, Japan) where a concentration of $0.2 \mathrm{mg} / \mathrm{mL}$ frog EPN in $0.1 \mathrm{~cm}$ path-length cuvette was used. The ellipticity data was fitted using a secondary structure estimation program K2D3 [18] to approximate the secondary structure content (Figure 3).

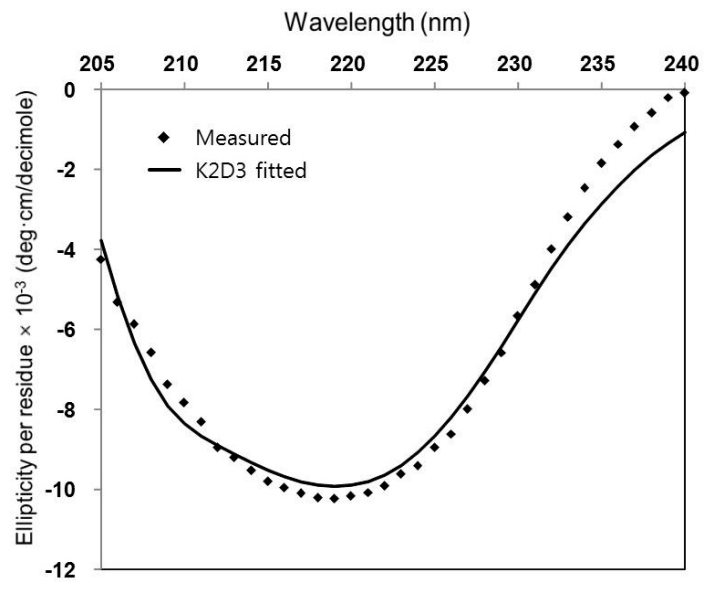

Figure 3. Circular dichroism study on the frog EPN.

\subsection{Crystallization}

Commercial screening solutions (Hampton Research, Aliso Viejo, CA, USA) were used to screen for frog EPN crystals. Single crystals appeared in a well reservoir of $0.2 \mathrm{M}$ Calcium acetate hydrate, 0.1 M Sodium cacodylate trihydrate $\mathrm{pH} 6.5$, and $18 \%(w / v)$ Polyethylene glycol 8000 in $\sim 2$ days over a hanging drop at $22{ }^{\circ} \mathrm{C}$ (Figure 3). A single crystal was transferred to a cryo-protectant solution which was made by adding glycerol to the reservoir solution to final $20 \%$ concentration, and flash-cooled in liquid nitrogen for storage. The frozen crystal was transported to a synchrotron facility where diffraction experiment was performed (Figure 4). 


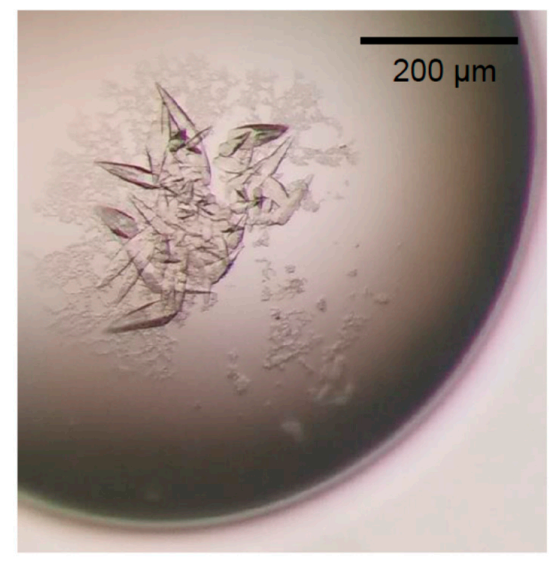

Figure 4. Crystals of frog EPN.

\subsection{Data Collection and Processing}

X-ray diffraction data were collected under a liquid nitrogen stream $(100 \mathrm{~K})$ on a CCD detector (ADSC Quantum Q270) at beamline 7A of PLS (Pohang, Korea). The crystal was rotated with $1.0^{\circ}$ oscillation per frame to a total of $180^{\circ}$ for complete data collection. Data were processed using HKL2000 [19] to a space group of $\mathrm{P}_{1} 22$ (or $\mathrm{P} 6_{5} 22$ ) (Table 2).

Table 2. Data collection and processing.

\begin{tabular}{|c|c|}
\hline Diffraction Source & Pohang Light Source (PLS 7A) (Pohang, Korea) \\
\hline Wavelength $(\AA)$ & 0.97934 \\
\hline Temperature $(\mathrm{K})$ & 100 \\
\hline Detector & ADSC Quantum Q270 \\
\hline Crystal-detector distance (mm) & 350 \\
\hline Rotation range per image $\left(^{\circ}\right)$ & 1 \\
\hline Total rotation range $\left(^{\circ}\right)$ & 180 \\
\hline Exposure time per image (s) & 1 \\
\hline Space group & $\mathrm{P}_{1} 22$ (or $\mathrm{P}_{5} 22$ ) \\
\hline$a, b, c(\AA)$ & $61.05,61.05,234.33$ \\
\hline$\alpha, \beta, \gamma\left({ }^{\circ}\right)$ & $90.0,90.0,120.0$ \\
\hline Mosaicity $\left(^{\circ}\right)$ & 0.496 \\
\hline Resolution range $(\AA)$ & $50.0-2.70(2.75-2.70)^{1}$ \\
\hline Total No. of reflections & 129,713 \\
\hline No. of unique reflections & 7871 \\
\hline Completeness (\%) & $99.6(100.0)$ \\
\hline Redundancy & $16.6(17.0)$ \\
\hline$\langle I / \sigma(I)\rangle$ & $43.8(3.7)$ \\
\hline$R_{\text {merge }}$ & $0.118(1.136)$ \\
\hline$R_{\text {p.i.m. }}$ & $0.029(0.271)$ \\
\hline $\mathrm{CC} 1 / 2$ & $(0.886)$ \\
\hline Overall $B$ factor from Wilson plot $\left(\AA^{2}\right)$ & 58.9 \\
\hline
\end{tabular}

${ }^{1}$ Values for the outer shell are given in parentheses.

\section{Results and Discussion}

Although EPN is a protein that is similar among various species (Figure 1), neither the functional role (other than in fish) nor the detailed mechanism of action are known. In this study, the DNA encoding the frog (X. tropicalis) EPN without the signal sequence was generated by gene-synthesis and cloned into a pAcGP67A vector for secreted recombinant expression in SF9 insect cells. Of note, all attempts in using Escherichia coli bacterial expression of the same protein in various vectors and competent cells failed, which led us to depend on the eukaryotic expression system of using insect cells. The EPN protein was 
successfully over-expressed in a soluble form and was secreted into the media. The SEC elution profile of initial Ni-NTA purified frog EPN on HiLoad ${ }^{\circledR} 26 / 60$ Superdex $^{\circledR} 200$ showed a single peak (Figure 2). The final SDS-PAGE analysis of the concentrated EPN protein under the peak indicated successful over-expression and purification of the EPN protein (Figure 2 inset). When looking at the size of the expressed frog EPN protein under reducing ( $5 \mathrm{mM}$ DTT) condition, the molecular mass estimated based on standard protein markers seems to be $\sim 33 \mathrm{kDa}$ (Figure 2 inset) while the expected size calculated from the protein sequence is $22.8 \mathrm{kDa}$. This increased size in SDS-PAGE may be due to the $\mathrm{N}$-glycosylations that are possible during expression within the insect cells. Also, unlike SDS-PAGE ran under reducing condition, non-reducing SDS-PAGE of the protein showed a single band corresponding to the size of a dimer. Hence, the frog EPN is likely associated into a dimer by at least one intermolecular disulfide bridge. The overall yield of the purified frog EPN was $\sim 3 \mathrm{mg}$ per $1 \mathrm{~L}$ of culture.

Due to the lack of functional studies that can be performed on the frog EPN, circular dichroism (CD) was used to determine that the recombinant protein had proper folding. Furthermore, secondary structure contents of frog EPN were estimated using the CD data (Figure 3). When the experimental ellipticity values of $205 \sim 240 \mathrm{~nm}$ range were fitted for secondary structure estimation, the result indicated that $\sim 19 \%$ of the protein are $\alpha$-helical and $\sim 33 \%$ of the protein are of $\beta$-strands (Figure 3).

Despite the fact that the purified frog EPN may contain $N$-glycosylation which often result in difficulties in crystallizing proteins [20], crystals of frog EPN were obtained by screening against commercial solutions (Figure 4). Single crystals were grown and optimized in a reservoir solution of $0.2 \mathrm{M}$ Calcium acetate hydrate, $0.1 \mathrm{M}$ Sodium cacodylate trihydrate $\mathrm{pH} 6.5$, and $18 \%(w / v)$ Polyethylene glycol 8000 at $22{ }^{\circ} \mathrm{C}$. In $\sim 2$ days, the EPN crystal grew to approximately $10 \mu \mathrm{m} \times 10 \mu \mathrm{m} \times 100 \mu \mathrm{m}$ (Figure 4) in size, which was sufficiently sized for X-ray diffraction experiments. The crystal diffracted well in a synchrotron $X$-ray radiation maintaining isotropic diffraction throughout all $180^{\circ}$ rotation (Figure 5). A total of 7871 unique reflections were measured throughout $180^{\circ}$ rotation and merged in the space group P6 22 (or P6 622 ) with unit cell parameters of $a=b=61.05 \AA$, and $c=234.33 \AA$. The merged dataset was overall $99.6 \%$ complete with $R_{\text {merge }}$ of $11.8 \%$ and $R_{\text {p.im. }}$. of $2.9 \%$ to $2.70 \AA$ resolution. Further diffraction statistics for the data collected are shown in Table 2. Matthews coefficient analysis [21] using the unit cell parameters, space group and the calculated molecular mass of protein only $(22.8 \mathrm{kDa})$ indicated that the crystal volume per protein mass $\left(\mathrm{V}_{\mathrm{M}}\right)$ of the EPN crystal was $2.76 \AA^{3} \mathrm{Da}^{-1}$ with $55.4 \%$ solvent content. Instead of the calculated molecular mass, using the apparent molecular mass of $\sim 33 \mathrm{kDa}$ from SDS-PAGE analysis, which likely results from $N$-glycosylation, led to $\mathrm{V}_{\mathrm{M}}$ of $1.90 \AA^{3} \mathrm{Da}^{-1}$ and $35.4 \%$ solvent content. In both cases, these values suggested that the asymmetric unit of EPN crystal likely contains only one subunit of the monomeric frog EPN. Because no model for EPN exists in the Protein Databank (PDB), attempts for phasing via molecular replacement couldn't be made.

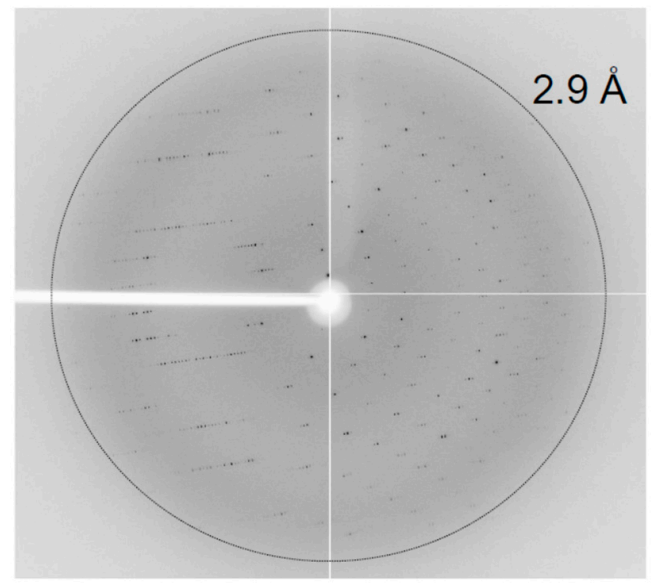

Figure 5. Isotropic X-ray diffraction image of frog EPN crystal. 
In the future, we plan to improve the current $2.7 \AA$ resolution crystal for better diffraction, and determine the high resolution structure of frog EPN by direct phasing. During the process, we plan to exploit conventional metal soaking [22] and other well-known techniques to work such as the use of $\left(\mathrm{Ta}_{6} \mathrm{Br}_{12}\right)^{2+}$ [23] or 5-amino-2,4,6-triiodoisophthalic acid [24], and even sulfur-SAD [25,26] or ultraviolet radiation damage-induced phasing (UV-RIP) [27] methods. Since no structural information on any EPN exists in databases, the structure would give us insight into understanding its function.

Author Contributions: SY.P. and J.K.P. conceived and designed the experiments; J.K.P. and Y.W.S. performed the experiments; J.K.P. analyzed the data; SY.P. wrote the paper.

Funding: This research was supported by the Basic Science Program through the National Research Foundation of Korea (NRF) funded by the Ministry of Science, ICT \& Future Planning (2016R1D1A1A09918187).

Acknowledgments: The authors would like to thank the staff at PAL 7A beamline for their support and beam time.

Conflicts of Interest: The authors declare no conflict of interest.

\section{References}

1. Shashoua, V.E. Brain metabolism and the acquisition of new behaviors. I. Evidence for specific changes in the pattern of protein synthesis. Brain Res. 1976, 111, 347-364. [CrossRef]

2. Benowitz, L.I.; Shashoua, V.E. Localization of a brain protein metabolically linked with behavioral plasticity in the goldfish. Brain Res. 1977, 136, 227-242. [CrossRef]

3. Shashoua, V.E. Brain protein metabolism and the acquisition of new patterns of behavior. Proc. Natl. Acad. Sci. USA 1977, 74, 1743-1747. [CrossRef] [PubMed]

4. Shashoua, V.E. Ependymin, a brain extracellular glycoprotein, and CNS plasticity. Ann. N. Y. Acad. Sci. 1991, 627, 94-114. [CrossRef] [PubMed]

5. Schmidt, R. Cell-adhesion molecules in memory formation. Behav. Brain Res. 1995, 66, 65-72. [CrossRef]

6. Tang, S.J.; Sun, K.H.; Sun, G.H.; Lin, G.; Lin, W.W.; Chuang, M.J. Cold-induced ependymin expression in zebrafish and carp brain: Implications for cold acclimation. FEBS Lett. 1999, 459, 95-99. [CrossRef]

7. Sneddon, L.U.; Schmidt, R.; Fang, Y.; Cossins, A.R. Molecular correlates of social dominance: A novel role for ependymin in aggression. PLoS ONE 2011, 6, e18181. [CrossRef] [PubMed]

8. Apostolopoulos, J.; Sparrow, R.L.; McLeod, J.L.; Collier, F.M.; Darcy, P.K.; Slater, H.R.; Ngu, C.; Gregorio-King, C.C.; Kirkland, M.A. Identification and characterization of a novel family of mammalian ependymin-related proteins (MERPs) in hematopoietic, nonhematopoietic, and malignant tissues. DNA Cell Biol. 2001, 20, 625-635. [CrossRef] [PubMed]

9. Gregorio-King, C.C.; McLeod, J.L.; Collier, F.M.; Collier, G.R.; Bolton, K.A.; Van Der Meer, G.J.; Apostolopoulos, J.; Kirkland, M.A. MERP1: A mammalian ependymin-related protein gene differentially expressed in hematopoietic cells. Gene 2002, 286, 249-257. [CrossRef]

10. Nimmrich, I.; Erdmann, S.; Melchers, U.; Chtarbova, S.; Finke, U.; Hentsch, S.; Hoffmann, I.; Oertel, M.; Hoffmann, W.; Müller, O. The novel ependymin related gene UCC1 is highly expressed in colorectal tumor cells. Cancer Lett. 2001, 165, 71-79. [CrossRef]

11. Müller-Schmid, A.; Rinder, H.; Lottspeich, F.; Gertzen, E.M.; Hoffmann, W. Ependymins from the cerebrospinal fluid of salmonid fish: Gene structure and molecular characterization. Gene 1992, 118, 189-196. [CrossRef]

12. Königstorfer, A.; Sterrer, S.; Hoffmann, W. Biosynthesis of ependymins from goldfish brain. J. Biol. Chem. 1989, 264, 13689-13692. [PubMed]

13. Shashoua, V.E.; Adams, D.; Boyer-Boiteau, A. CMX-8933, a peptide fragment of the glycoprotein ependymin, promotes activation of AP-1 transcription factor in mouse neuroblastoma and rat cortical cell cultures. Neurosci. Lett. 2001, 312, 103-107. [CrossRef]

14. Adams, D.S.; Hasson, B.; Boyer-Boiteau, A.; El-Khishin, A.; Shashoua, V.E. A peptide fragment of ependymin neurotrophic factor uses protein kinase $C$ and the mitogen-activated protein kinase pathway to activate c-Jun N-terminal kinase and a functional AP-1 containing c-Jun and c-Fos proteins in mouse NB2a cells. J. Neurosci. Res. 2003, 72, 405-416. [CrossRef] [PubMed]

15. Kaska, J. Ependymin Mechanism of Action: Full Length EPN vs Peptide CMX-8933. Master's Thesis, Worcester Polytechnic Institute, Worcester, MA, USA, 28 May 2003. 
16. Suárez-Castillo, E.C.; García-Arrarás, J.E. Molecular evolution of the ependymin protein family: A necessary update. BMC Evol. Biol. 2007, 7, 23. [CrossRef] [PubMed]

17. Gill, S.C.; von Hippel, P.H. Calculation of protein extinction coefficients from amino acid sequence data. Anal. Biochem. 1989, 182, 319-326. [CrossRef]

18. Louis-Jeune, C.; Andrade-Navarro, M.A.; Perez-Iratxeta, C. Prediction of protein secondary structure from circular dichroism using theoretically derived spectra. Proteins 2012, 80, 374-381. [CrossRef] [PubMed]

19. Otwinowski, Z.; Minor, W. Processing of X-ray Diffraction Data Collected in Oscillation Mode. Methods Enzymol. 1997, 276, 307-326. [CrossRef] [PubMed]

20. Chang, V.T.; Crispin, M.; Aricescu, A.R.; Harvey, D.J.; Nettleship, J.E.; Fennelly, J.A.; Yu, C.; Boles, K.S.; Evans, E.J.; Stuart, D.I.; et al. Glycoprotein Structural Genomics: Solving the Glycosylation Problem. Structure 2007, 15, 267-273. [CrossRef] [PubMed]

21. Matthews, B.W. Solvent content of protein crystals. J. Mol. Biol. 1968, 33, 491-497. [CrossRef]

22. Pike, A.C.; Garman, E.F.; Krojer, T.; von Delft, F.; Carpenter, E.P. An overview of heavy-atom derivatization of protein crystals. Acta Crystallogr. D Struct. Biol. 2016, 72, 303-318. [CrossRef] [PubMed]

23. Pasternak, O.; Bujacz, A.; Biesiadka, J.; Bujacz, G.; Sikorski, M.; Jaskolski, M. MAD phasing using the (Ta6Br12)2+ cluster: A retrospective study. Acta Crystallogr. D Struct. Biol. 2008, 64, 595-606. [CrossRef] [PubMed]

24. Sippel, K.H.; Robbins, A.H.; Reutzel, R.; Domsic, J.; Boehlein, S.K.; Govindasamy, L.; Agbandje-McKenna, M.; Rosser, C.J.; McKenna, R. Structure determination of the cancer-associated Mycoplasma hyorhinis protein Mh-p37. Acta Crystallogr. D Struct. Biol. 2008, 64, 1172-1178. [CrossRef] [PubMed]

25. El Omari, K.; Iourin, O.; Kadlec, J.; Fearn, R.; Hall, D.R.; Harlos, K.; Grimes, J.M.; Stuart, D.I. Pushing the limits of sulfur SAD phasing: De novo structure solution of the $\mathrm{N}$-terminal domain of the ectodomain of HCV E1. Acta Crystallogr. D Struct. Biol. 2014, 70, 2197-2203. [CrossRef] [PubMed]

26. Gorgel, M.; Bøggild, A.; Ulstrup, J.J.; Weiss, M.S.; Müller, U.; Nissen, P.; Boesen, T. Against the odds? De novo structure determination of a pilin with two cysteine residues by sulfur SAD. Acta Crystallogr. D Struct. Biol. 2015, 71, 1095-1101. [CrossRef] [PubMed]

27. Foos, N.; Seuring, C.; Schubert, R.; Burkhardt, A.; Svensson, O.; Meents, A.; Chapman, H.N.; Nanao, M.H. $\mathrm{X}$-ray and UV radiation-damage-induced phasing using synchrotron serial crystallography. Acta Crystallogr. D Struct. Biol. 2018, 74, 366-378. [CrossRef] [PubMed] 